\title{
HEINONLINE
}

Citation: 83 Yale L.J. 883 1973-1974

Content downloaded/printed from

HeinOnline (http://heinonline.org)

Wed Apr 6 16:15:08 2011

-- Your use of this HeinOnline PDF indicates your acceptance of HeinOnline's Terms and Conditions of the license agreement available at http://heinonline.org/HOL/License

-- The search text of this PDF is generated from uncorrected OCR text.

-- To obtain permission to use this article beyond the scope of your HeinOnline license, please use:

https://www.copyright.com/ccc/basicSearch.do?

\&operation $=$ go\&search Type $=0$

\&lastSearch $=$ simple\&all=on\&titleOrStdNo=0044-0094 


\title{
The Yale Law Journal
}

Volume 83, Number 5, April 1974

\section{The National Court of Appeals: An Unwise Proposal}

\author{
Charles L. Black, Jr.†
}

"Talk like a lawyer!" That exhortation, in a voice that to the firstyear student seemed crackling thunder, came down upon us from our young instructor, James William Moore, whose teaching specialty, I think, was then and has remained the professionalization of his students-a process indispensable to every other accomplishment in their lives to come. We, his students, now thousands in number, owe him much. I really don't know whether, in this article, I am repaying him by agreement or by disagreement with his own views, but I do know that that will make little difference to him, if only I talk like a lawyer. And I know my subject must be of keenest interest to one of the most thoroughly versed minds in this century on matters of federal jurisdiction.

A Study Group on the Case Load of the Supreme Court has recently made findings and very drastic recommendations. ${ }^{1}$ If I did not know that some qualified persons do disagree with the main finding of the

$\dagger$ Henry R. Luce Professor of Jurisprudence, Yale University.

1. Report of the Study Group on the Caseload of THE SUPREMe Court (1972) [hereinafter cited as REPORT]. I have not by any means seen all of the doubtless abundant literature on this topic; I think I must have seen at least some of the best of the advocacy favoring the Report in Freund, Why We Need a National Court of Appeals, 59 A.B.A.J. 247 (1973), and A. BickeI, THE Caseload OF THE Supreme Court and What, If Anything, to do About It (1973) [hereinafter cited as Bickel]. On the contra side, which is mine, I would owe much more than I do to Gressman, The National Court of Appeals: A Dissent, 59 A.B.A.J. 253 (1973), were it not that my own piece was outlined and partly written before I saw his article; I am sure he will agree that opposition to this Report should be argued in as many places and by as many people as possible, with the inevitable overlaps and shadings of difference. I have benefitted generally from Blumstein, The Supreme Court's Jurisdiction-Reform Proposals, Discretionary Review, and Writ Dismissals, 26 VANDERBILT L. REv. 895 (1973). Through the years, I have discussed many problems concerning the judiciary with Congressman Bob Eckhardt, and owe him a general debt as to anything I write on the subject-with the usual reservation that he is in no way responsible for any view stated here. The same things may be said of Alexander Bickel, with whom, on this issue, I disagree. 
Group ${ }^{2}$-the finding, in brief, that the Supreme Court either now is or (if its present pattern of doing business continues unchanged) shortly will be far too overworked to do its job well, or even passably-I should have thought this beyond debate or doubt. The statistics still seem to me to be of unrebutted grimness. I am going to assume here that this finding is right.

The Study Group locates the phase in the Court's work at which pressure might most suitably be relieved: the phase of decision as to which cases are to be taken or, roughly, the point at which decisions on grant or denial of certiorari are made. ${ }^{3}$ Here again, it seems to me the Group is probably right. If reorganization must be tried somewhere, it is here, rather than at the stage of final decision, that it should first be tried.

With the Group's chief recommendation of remedy I firmly disagree. I set out what I take to be its essence, in the Study Group's own words:

We recommend creation of a National Court of Appeals which would screen all petitions for review now filed in the Supreme Court, and hear and decide on the merits many cases of conflicts between circuits. Petitions for review would be filed initially in the National Court of Appeals. The great majority, it is to be expected, would be finally denied by that court. Several hundred would be certified annually to the Supreme Court for further screening and choice of cases to be heard and adjudicated there. Petitions found to establish a true conflict between circuits would be granted by the National Court of Appeals and the cases heard and finally disposed of there, except as to those petitions deemed important enough for certification to the Supreme Court.

The composition of the National Court of Appeals could be determined in a number of ways. The method of selection outlined here draws on the membership of the existing courts of appeals, vesting the judges of those courts with new functions in relation to the new Court. The National Court of Appeals, under this plan, would consist of seven United States circuit judges in

2. See, e.g., Tidewater Oil Co. v. United States, 409 U.S. 151, 174-78 (1972) (Donglas, J., dissenting); Brennan, Justice Brennan Criticizes National Court of Appeals Proposal, 59 A.B.A.J. 835, 836 (1973); Goldberg, One Supreme Court: It Doesn't Need Its Cases Screened, New Republic, Feb. 10, 1973, at 14-15; Gressman, supra note 1; Warren, Retired Chief Justice Warren Attacks, Chief Justice Burger Defends Freund Group's Composition and Proposal, 59 A.B.A.J. 724, 72627 (1973). For a rebuttal of much of this criticism, see BickEL, supra note 1, at 20-37.

3. See Rerorr, supra note 1 , at $1-9,15-18$. It is less than clear how much of the time pressure on the Court arises from the necessity for reading certiorari petitions, but one should at least try improvement here. What seems a secondary feature of the proposal is its provision for intercircuit conflict resolution. See id. at 18, 21 \& p. 898 infra. 
active service. Assignment to this Court should be for limited, staggered terms. Thus the opportunity to serve on the National Court of Appeals would be made available to many circuit judges, the Court would draw on a wide range of talents and varied experience while not losing its identity and continuity as a court, and the burden of any personal inconvenience would not fall too heavily on any small group of judges. Appointments should be made by a method that will ensure the rapid filling of vacancies, and itself tend to provide the court with the widest diversity of experience, outlook and age, in order to help secure for it the confidence of the profession, of the Supreme Court, and of the country.

Assignment of circuit judges to the National Court of Appeals could be made for three-year staggered terms by a system of automatic rotation ....

\section{Constitutionality}

I am so little disposed to emphasize the constitutional question raised by this proposal that $I$ hesitate to discuss that question at all. Yet I must, for I decidedly think the proposal unconstitutional. A court that can finally determine, for the whole nation, questions over the whole range of federal law, without the possibility of further review, is a "Supreme Court" in everything but name, and the Constitution provides for one Supreme Court, quite as clearly as it provides for one President. This National Court of Appeals could and would do just this, in two ways, one entirely open and one scarcely hidden. First, as the quotation just above shows, this National Court of Appeals could do just what I have said only a "Supreme Court" can do, in any case of intercircuit conflict, whatever the question might be. This new Court then, would (in its own unreviewable discretion) be a "Supreme Court," for the entire nation, on the full and final merits of all questions where, in its own view, an intercircuit conflict happened to have arisen. ${ }^{\circ}$ Secondly, as much in the Report seems to assume, and as every practitioner's common sense tells him, the most frequent reason for

\section{REPORT 18-19.}

5. "Important" questions on which intercircuit conflict is thought to exist might be "certified" by the National Court to the Supreme Court, but the Supreme Court would have no control over this, except by the "certiorari before judgment" route, see id. at 21,23 , which, for reasons given in the text, seems to me illusory. See p. 887 infra.

It would be a possibility, under the Report's proposal, that actual conflict could develop and stand for a time unresolved between the Supreme Court and the National Court of Appeals. This is unlikely, in naked form, but conflict of tendency and doctrinal trend might easily arise and persist. The avoidance of this scandal is one excellent reason for having only "one Supreme Court." 
denying a petition for certiorari is that it is thought utterly to lack foundation in law. As long as petitions are disposed of by the same Court as that which would deal with the merits, there is no harm and much good in fudging a little and saying that the denial of certiorari never has anything to do with the merits. This fiction-and in a great many cases it is only that-serves the good purpose of leaving open, for the future, questions summarily dealt with; what may seem obvious today may seem more than doubtful 10 years hence, and today's unpondered judgment of obviousness ought not to bind the Court when the obviousness has weathered away, revealing a rocky question underneath. But the fiction has to be penetrated when it is sought to give unreviewable finality, at the top of judgment, to a new and second Court's action in denying access to full review.

Bickel has said this argument "rests on a word play." ${ }^{\text {I }}$ s submit that the real playing with words is to be found in the creation of a Court with final power to decide federal questions of all sorts for the whole nation, while scrupulously refraining from calling that Court "Supreme," just so we can go on saying we have only "one Supreme Court," as Article III commands. Bickel's examples of past congressional dealings are one and all broadly and crucially distinguishable, for they excepted from or regulated the exercise of the uniquely "supreme" appellate review ${ }^{7}$ rather than providing an alternative supreme appellate review-just what we cannot do if we are to have "one Supreme Court." The trouble with the shade-by-shade logic that could lead to this is that it could take us on a little further to the nearly-complete substitution of a second Court (or a third Court, or a fourth Court), in the colloquial sense "supreme," for doing the work belonging to the one supreme Court set up by the Constitution. And it should be noted that this National Court proposal violates another exceedingly important command of Article III, in that its members do not enjoy life tenure during good behavior, insofar as concerns their membership on this (for many purposes) top appellate court, "supreme" in all but name.

6. Bickel, supra note 1 , at 35 .

7. Even here, it seems to me, Bickel sees the material from only one side. As to criminal appeals, for example, all state criminal cases, by far the more important, have always been within the Court's appellate jurisdiction whenever a federal question was present. Before 1891, habeas corpus served much of the office of appeal from federal criminal convictions, sometimes from within the Court's original jurisdiction. See P. Bator, P. Mishkin, D. Shapiro \& H. Wechsler, Hart \& Wechisler's Federal Courts AND THE FEDERAL SYSTEM 1430-31 (2d ed. 1973).

On the policy level, of course, the argument by analogy from a limitation that was dropped 83 years ago, presumably because it was found undesirable, fails-or rather succeeds in reverse. 
And the proposal may also infringe the requirement that Supreme Court Justices be confirmed, as such, by the Senate. ${ }^{8}$

Perhaps it might be sought to get around some or all of these objections by pointing to the fact that, on application, the Supreme Court itself might, under the proposal, grant certiorari "before judgment" as to any case pending in the National Court of Appeals. ${ }^{\circ}$ But the litigant who took this route would have to bear the handicap of seeming to fear that his case would not even pass the supposedly less strict screening of the National Court. He would also be asking the Supreme Court for something which it must, for institutional and comity reasons, be reluctant to grant, aside from the merits. ${ }^{10}$ It seems pretty plain, moreover, that denial of certiorari by the Supreme Court itself, on application before judgment, would to some extent prejudice the application in the National Court of Appeals; indeed, if it were absolutely free of such effect, it would be malpractice not to apply for it routinely, so as to have two chances rather than one for full review. The "before judgment" requirement encourages a race; the uncertainty as to prejudicial effect sets up an unseemly invitation to gamble. I do not think such an alternative cures the constitutional defect; I feel very certain, at the least, that Congress ought not to sail anything like that close into the wind. Congress may note and act so as to avoid a perceived violation of the spirit and manifest tendency of the Constitution, even if a court might have to hold that the statute satisfied the more constricted test a court can apply.

\section{Policy Considerations}

But let me now very firmly say goodbye to this constitutional question. It should never be reached, for on grounds of policy the proposal is exceedingly unwise. In seeking to establish this, I shall first try to remind the reader of the absolutely crucial importance of the case-selection process and then invite attention to what I take to be critical defects in the composition of the proposed tribunal.

I shall assume, throughout, the acceptance of the Report's recommendation that "appeal" be abolished and that all cases be treated along "certiorari" lines. This, as all know, is a fairly close approxi-

8. For the crucial importance of this function, and the wide scope of considerations open to the Senate, see Black, $A$ Note on Senatorial Consideration of Supreme Court Nominees, 79 Yale L.J. 657 (1970).

9. See REPORT, supra note 1, at 21.

10. The Report, I think euphemistically, concedes that its recommendations rest on the premise that certiorari before judgment is "not a procedure to be encouraged." Id. at 23 . 
mation to what happens now, and stated rule should be brought into line with usual practice. The ancient categories of "appeal" make no sense anymore. ${ }^{11}$ In the following examples, then, it will be irrelevant whether the very cases mentioned reached the Court through "certiorari" or "appeal," for I am considering what would have happened had the Report's proposal been in effect.

\section{A. The Screening Function}

Now it might at first seem that the function of "screening" cases for the Supreme Court's review is sort of "mere"- "ancillary" or "preliminary." Fortunately, the exposure of this plain and potentially disastrous error does not depend on bare theory, but rests instead on theory that emerges, so clearly as not to need explicit stating, from the experience of the decades. Let us take the last five or six decades; they are the most important to our times. With crushing and unidirectional force, the experience of these decades shows that the power to select cases-even cases that to the profession at large might seem off-beat or unpromising-is a good half, or more, of the power to shape constitutional law and that, reciprocally, the function of the Supreme Court, as shaper of constitutional law, would be in total jeopardy if that Court were stripped of its power to select the cases it will hear and determine. Examples could form a full-bodied treatise on the constitutional law of the twentieth century, for the same truth would easily emerge as to every single trend. Let me give just a few examples.

When Gitlow ${ }^{12}$ came to the bar of the Court, it was very dubious whether the national Constitution to any extent at all protected free speech against infringement by the states. There was an exceedingly strong dictum (at least) to the contrary. ${ }^{13}$ In any case, there was not, even in the Gitlow opinion, any hint of anything like a "preferred" position, and without such a position, thrown back on general "due process," Gitlow was pretty sure to lose and go to prison, as he did. Suppose a "National Court of Appeals," in part surveying and in part correctly anticipating this state of things, had decided the Supreme Court should not waste its time on such an unpromising case.

11. See Gressman, supra note 1 , at 258 .

12. Gitlow v. New York, 268 U.S. 652 (1925).

13. Prudential Insurance Co. of America v. Cheek, 259 U.S. 530, 543 (1922). ("But, as we have stated, neither the Fourteenth Amendment nor any other provision of the Constitution of the United States imposes upon the States any restrictions about "freedom of speech .... .") This in a Pitney opinion for the Court, joined by Holmes and Brandeis, three years before Gitlow. 
Nobody dissented from the result in Whitney; ${ }^{14}$ Stromberg ${ }^{15}$ did not even involve speech in the literal sense. Might not a conscientious panel of the National Court of Appeals have thought such cases not worth the Supreme Court's while? After Dennis, ${ }^{16}$ might it not have been judged that Yates $^{17}$ was a mere mop-up operation? Was the petition for certiorari in a case invoking the First Amendment against the state common law of libel (New York Times $v$. Sullivan $)^{18}$ not one which might well have been denied, it being so widely received a view that libel was a clear-cut exception to the free speech guarantee? ${ }^{10}$

Notice that I am not saying that a National Court of Appeals would have denied access to the Supreme Court in any or all of these cases. I am simply saying that this is clearly possible and would have fallen well within the bounds of good faith. And, much more importantly, I am saying that the act of taking these cases was an absolutely inexcisible part of the process of moving this sector of constitutional law along; that if the Supreme Court had been prevented from even so much as hearing some or all of these cases-as it obviously might have been under the current proposal-the modern law of free speech almost certainly would have been unrecognizably different from what it is.

Plessy v. Ferguson ${ }^{20}$ was a fixed star, and almost all "sound" lawyers thought it broadly validated the hateful segregation regime.21 How could you possibly separate the act of overruling this monstrous case from the act of deciding whether to consider overruling it-itself a great policy decision which would have been visibly irresponsible to make in entire abstraction from an educated guess as to how the case would come out? Might not a randomly selected panel of "sound" circuit judges have denied certiorari?

Flast v. Cohen ${ }^{22}$ might well have seemed, to any given National Court of Appeals for the time being, to be so evidently ruled by Frothingham v. Mellon ${ }^{23}$ as to make the granting of certiorari absurd. ${ }^{24}$ For my part, I think this is what should have been held in

14. Whitney v. California, 274 U.S. 357 (1927).

15. Stromberg v. California, 283 U.S. 359 (1931).

16. Dennis v. United States, 341 U.S. 494 (1951).

17. Yates v. United States, 354 U.S. 298 (1957).

18. 376 U.S. 254 (1964).

19. See cases cited in New York Times v. Sullivan, 376 U.S. at 268 n.6.

20. 163 U.S. 537 (1896).

21. See W. Harbaugh, Lawyer's Lawyer: The Life of John W. Davis 154 (1973).

22. 392 U.S. 83 (1968).

23. 262 U.S. 447 (1923).

24. Here, again, it must be obvious that a vote for or against certiorari, on the "standing" question, involves a major policy decision as to the role of courts. 
the Supreme Court, ${ }^{25}$ and I (as I now think, improperly) wrote the only letter I ever wrote to a judge on an opinion of his, just to express to the late Mr. Justice Harlan my warm agreement with his Flast dissent. But I am not here selecting only cases or trends with which I agree, but am attempting rather to demonstrate, out of massive and uncontradicted experience, the absolutely commanding character of the position at the gate.

Would a National Court of Appeals have found arguable merit in a petition for certiorari in Baker $v . \mathrm{Carr}^{26}$ given the widely diffused professional understanding, ${ }^{27}$ expressed in the lower court opinion, ${ }^{28}$ that Colgrove v. Green ${ }^{29}$ and the per curiam opinions following it $^{30}$ had settled that the courts had no business dealing with legislative apportionment? When, and on what basis, would a National Court of Appeals have decided that the time might have come for the Supreme Court to reconsider and perhaps overrule the earlier cases so clearly refusing to apply the exclusionary rule to state criminal trials? ${ }^{31}$ Would not the power of life and death have been implied in control of the flow to the Supreme Court of the capital punishment cases ${ }^{32}$ The half-and-half collision damages rule in admiralty is as well established as a rule of law can be; has the time come to reconsider and perhaps to change it? ${ }^{33}$ Is not the answer to the last question an absolutely crucial part of the decision on the merits?

Let us take the present not-quite-Nixon Court. Suppose its new majority desires to effect some partial and tactful retreat from some of the advanced pretrial due process positions of its predecessor, or carefully to limit some of the previously commenced lines of development. Is not the mapping of such policy what we expect of Supreme Court Justices? And how could this trend be effected, be made neither more nor less than what was desired, if another court altogether selected the cases?

Selection of cases is probably the most important part of development of the law (if one may hope someday to be able to call it that) of obscenity.

25. See Black, Religion, "Slanding," and the Supreme Court's Role, 13 J. PuB. Law 459,469 passim (1965), where I uttered the remarkable prophecy that the Court would not "overrule or seriously modify Frothingham." Id. at 469.

26. 369 U.S. 186 (1962).

27. See R. Dixon, Democratic Representation 113-14, 118 (1968).

28. See Baker v. Carr, 179 F. Supp. 824, 826 (M.D. Tenn. 1959).

29. 328 U.S. 549 (1946).

30. Cited in Mr. Justice Frankfurter's dissent in Baker v. Carr, 369 U.S. at 270 n.1.

31. See Mapp v. Ohio, 367 U.S. 643 (1961).

32. See Furman v. Georgia, 408 U.S. 238 (1972), and the closely preceding cases cited therein.

33. See Union Oil Co. v. The San Jacinto, 406 U.S. 942 (1972). 
This could go on forever. The Report's proposal withdraws from the Court a function that is not just "ancillary," "preliminary," or in any sense "mere." The National Court of Appeals is not a simple time-saver. The proposal strikes at the vitals of the Supreme Court's functions. What we need is a new Bishop Hoadly to preach to us that "Whoever hath an absolute authority to control the nature and scope of questions to be decided is to all intents and purposes controller over the process of decision."34 The authors of this Report are recommending amputation of the right arm as a cure for overweight.

The radical vice of this proposal, then, is its attempted separation of the act of supremely important decision from the decision whether to perform this act, and when to perform it. Experience shows this to be unsound; theory shows it to be unsound. (I have to say that I am rather bewildered by the fact that Bickel supports such a proposal; it seems to me he would more expectedly have taken on the role of our Bishop Hoadly redivivus, for he, more than anyone since the beginning, has shown us how important is the subtle use of the passive virtues. I should have thought that this subtlety must imply the power to choose; that, without this power to choose, the "passive virtues" lose the name and the efficacy of virtue and become mere passivity.)

The Study Group's proposal would then, in my view, be wrong, whatever composition the gatekeeper court might have. But there are important things wrong with the character and composition of the proposed "National Court."

\section{B. Composition and Institutional Continuity}

As to the provision of the National Court's personnel, the general professional competence of its judges would of course be assured, in overwhelming preponderance, by their being taken in rotation from among the judges of the courts of appeals. It cannot be denied, and I have no impulse to deny, that a good many of these judges would be as well up as one can be to the rather mind-boggling task of deciding whether another court should decide a given question. But we have to deal with the general case, and with the whole run. It can be said confidently, though regretfully, that the mode of selection of circuit judges is not such as to push toward the naming of persons with the broadest possible national view. The selection process has a strong sectional flavor; the influence of particular senators,

34. Hoadly's Sermon preached before the King, March 31, 1717, quoted in W. LockharT, Y. KAMis.tR AND J. Choper, Constitutional LAW 1 (3d ed. 1970). 
rather than of the whole Senate, is often-perhaps more often than not-dominant. ${ }^{35}$ Nor are the traits required for the skillful processing of a large number of miscellaneous appeals necessarily accompanied by the kind of overall strategic vision requisite to the wise control of the business of the Supreme Court. ${ }^{36}$

On the other hand, circuit judges are professionals of distinction and high quality, to whom the mere weeding out of obviously deficient certiorari petitions would be repugnant as a three-year work. ${ }^{37}$ Such persons would, I tremblingly guess, probably be motivated to make something more than that of their function-to import pattern and substantial policy into the process of granting or denying certiorari. But insofar as they did this they would be visibly trenching upon one of the most vital functions of the Supreme Court. This same tendency might well lead the National Court of Appeals to retain, and to determine, some cases of intercircuit conflict which, because of their importance, ought to go to the Supreme Court. After all, what professional of quality and high prestige likes to see his function as principally routine and, when not routine, as relatively unimportant? Is pressure not thus generated against the doors of escape? The question is not whether the judges of the National Court of Appeals would consciously set out to shape policy by certiorari determinations or by retaining and deciding intercircuit conflict cases of high importance. The question is rather whether it is wise so to structure a situation as to place them under continual temptation to do these things-to make their abstention from these things equivalent to their making their own work boring and rather unimportant.

Resistance to being doomed to the merely boring and unimportant is perhaps the last infirmity of noble judicial mind. The first foolishness of political mind is so to form an institution as to put those within it under continual temptation to do something not wanted, trusting to integrity and to immunity from self-deception to ensure that the temptation not be yielded to. In sum, the proposed mode of manning the National Court of Appeals tends to maximize the probability that it will become a second "Supreme Court."

On the other hand, there is no remedy to be found in manning a gatekeeper court with inferior personnel, with people glad of the

35. See H. Jacob, Justice in America: Courts, Lawyers, and the Judicinl Process 90 (1965).

36. See Brennan, supra note 2 , at 840 .

37. See, e.g., BICKEL, supra note 1 , at 20; H. FriendLX, FeDERAL JuRisdiction: A General. View 52 (1973); Warren, supra note 2, at 729 . Bickel replies that circuit judges will serve on the National Court of Appeals as "a necessary public duty." BickEL 36. 
work: The unwisdom of that speaks for itself. The problem is simply insoluble, and it is that exactly because it is only an aspect of the clearly insoluble problem of separating the policy of decision from the policy of the decision to decide.

Other miscellaneous and now only partly foreseeable warping stresses might appear. I think there may well be much in Gressman's suggestion ${ }^{38}$ that circuit judges might be unconsciously influenced by their built-in loyalty to the lower-court system-influenced, for example, by sympathy for lower court judges who, like the members of the three-judge court in Baker v. Carr, ${ }^{39}$ have faithfully followed what seemed to be the tendency of prior Supreme Court judgments.

There remains the question of institutional continuity in this proposed National Court. Here I quote Bickel, for he seems to me to confess the desirability of this, while utterly failing to avoid:

One troublesome criticism remains. That is the criticism that the new court would lack cohesion, continuity, and indeed identity as a court because, for the most part, it would not be engaged in the usual process of hearing argument, deliberating, and rendering decision on the merits of cases, but rather in screening. If the court is established, perhaps the importance of its function, the fact that it would have a number of cases to hear and decide on their merits each year, the growing confidence of the profession and of the country in the court's performance of its function with fidelity and skill-perhaps all that would sustain the new court as an institution. It is not visionary to hope so. ${ }^{40}$

The last sentence is to be noted. "Visionary" is an attribute doubtful of accurate predication. Perhaps one could substitute another sentence of Bickel's, in the same paper, quoted from Hemingway: "[I] sn't it pretty to think so?"'11 The question really is not whether it is pretty to think, or visionary to hope, that this new Court could acquire any institutional continuity. The question is whether this result seems likely. And here I think Bickel does the material less than justice. For the greatest (and to me surely insurmountable) obstacle to the achievement of continuity is the term of service. There are to be "staggered" terms of three years. I am ill at reckoning, but I take it that this means that there would be a wholly new court every three years, and a new majority, at least, every two years or less. No Presi-

38. Gressman, supra note 1 , at 257 .

39. 179 F. Supp. 824 (M.D. Tenn. 1959).

40. BICKEL, supra note 1 , at 37 .

41. Id. at 34, quoting E. HeMingway, The Sun Also Rises (1926). 
dent, at the end of his first term, would see anybody on this court who had been on it on Inauguration Day. I cannot think, accordingly, that "institutional continuity" is a serious possibility. A more serious issue, to me, would be the forum-shopping through time which might result when change in the court's majority is always known with certainty to impend, and when the identity of the new judges-to-be is certainly known.

I would conclude, and I rather sense that by now the major pars have concluded, that this National Court proposal is unwise. But mere rejection is by no means enough. The Chief Justice has said:

Reasonable men can disagree over the particular kind of intermediate court recommended by [the study group] and the powers of that court, but no person who looks at the facts can rationally assume that nine Justices today can process four or five times as many cases as the Courts that included Taft, Holmes, Brandeis and Hughes-to mention only a few-and do this task as it should be done. It is a flattering thought that we of today's Court possess such extraordinary capacities, but it is a superficial reaction to a serious study. To suggest, as has been done, that additional law clerks can take up the increased load may flatter the ego of law clerks, but I suggest that the public and the profession want the decisional functions to be exercised by judges. . . Few have challenged the existence of a grave problem, and now it is the plain duty of the profession to explore all possible avenues for solutions. Sterile, negative criticism is of little use to anyone, and it is the obligation of those who disagree with the solutions proposed to offer their own alternatives. I will continue to defer my conclusions on this subject until I see the alternatives."

I think this challenge (or plea) must be taken seriously. But I also insist, as the Study Group has done with respect to its own solution, ${ }^{43}$ that one must accept the fact that any change is likely to be less than wholly desirable in itself, and that suggestions must be weighed not against the ideal, but against other possibilities.

\section{Alternatives}

In this frame, I would not hesitate to choose to let oral argument go, rather than to locate control of the screening process outside the Supreme Court. ${ }^{44}$ Such a step would be most unpleasant, but I think

42. Address to the American Bar Association, August 1973, quoted in Bicker 14.

43. REPORT, supra note 1 , at 22 .

44. But cf. REPORT 42. "'The Committee would not suggest that the Court could or should abandon oral arguments or reduce the argument time from the present standards.") 
one ought to take it unflinchingly, if it became necessary, for it would retain the absolutely vital at the expense of the highly desirable. But I do not think this choice is now shown to be necessary.

\section{A. Staff Expansion}

Keeping in reserve for now the possibility of dropping (or selectively dropping) oral argument, I would instead pick up Gressman's suggestion $^{45}$ that the possibilities of greater use of staff be explored much more fully than the Study Group has explored it. And I think this exploration ought to be experiential rather than hypotheticalthat a prudent expansion of staff ought to be tried, not just written about-before one thinks of more drastic remedies.

Since proposals must precede experiment, I will say something as to what $I$ have in mind. The key concept, it seems to me, ought to be expansion of the staff of each individual Justice rather than expansion of the Court's collective staff, though it is not impossible that some expansion and reorganization of the latter could so be done as to save all members of the Court some time.

I suggest that each Justice be furnished perhaps two more law clerks and two or three relatively permanent senior people. All of these people should be responsible to the Justice and to him alone. We would then have a Court in which each Justice would have seven or eight professional staff people assisting him-not anything like the "corporate aggregate" the Study Group fears." Members of the staff and the Justice could become intimately familiar with each other by working in daily close collaboration. (Whether they actually would must depend, then as now, on the individual Justice.)

In a general way, I should think it likely that such an expansion of staff could lighten the load of the Justice at many points. Of course any Justice could use his people in any way he desired. In the absence of any really adequate information from the Study Group on the work patterns of the Justices, it seems a most improbable assumption that there are no routines which could be delegated, quite aside from the certiorari-petition routine. But since it is to the latter that the Study Group addresses most of its thought, let us consider what contribution expanded staff might there make.

There is no point in pretending that the timesaving use of staff in processing certiorari petitions can produce an ideal solution. The ideal and quite unattainable goal would be that every Justice care-

45. Gressman, supra note 1 , at 255 .

46. See REPORT 7 . 
fully ponder (and, where needful, ponder a second or third time) every word of every document filed. I think, however, that staff procedures could be worked out to save a great deal of each Justice's time and nevertheless to minimize to just about zero the chances of dismissal of any case which four Justices would, after such careful consideration, have taken-and those are the two most urgent practical goals.

Every Justice must, of course, be free to organize his flow of business in his own way. But I can think of at least one way which would seem virtually to eliminate the chance of dismissal of any petition which would have been taken if each Justice had had 10 working days to ponder the matter.

\section{First Stage Screening}

Let us suppose that every petition (for simplicity, I shall use this word to refer to both petition and brief in opposition) were to be read carefully and independently by two professionals on each Justice's staff, themselves thoroughly acquainted and sympathetic with the particular Justice's priorities and totally responsible to him. Each of these people could summarize in writing the issues and contentions, adding a recommendation with short grounds therefor, and then compare results. If these were substantially identical, the summary and recommendation should go to the Justice, who would not, of course, be foreclosed from further inquiries, formal or informal. If there were disagreement on either the accuracy of the summation or the recommendation, a third professional on the staff could be called upon; if the disagreement persisted, then the full petition should go forward to the Justice. If all three staff members, after consultation, reached the same conclusions, their agreed-upon summary and recommendation should go to the Justice, who then might either cast a tentative vote or, if he wished, call for the full petition.

This procedure is rather complicated and time-consuming to be sure-but not for the Justice.

Where the staff recommendation was for granting the petition or was dubitante, summary and grounds should also be given, but the petition itself should go forward. The Justice might regard the case as a clear one for granting certiorari and cast his vote in that sense without closely reading the petition; in the case of the dubitante recommendation, he would probably want to look at all the material -particularly if his inclination after reading the summary was to deny. Now something like that could be the first stage. I doubt that very 
much, positive or negative, would really be lost if this were all. But there could be a quite independent second stage, which seems to me to promise virtually certain elimination of any inadvertence.

\section{Second Stage Cross-Check}

The votes coming from each Justice at the end of this first process should be preliminarily registered and circulated. If the requisite four votes were already in, certiorari should forthwith be granted. But if there were from one to three votes for granting, then the Justices voting negatively ought to reexamine the matter, with such staff help as is desired, and a second and final vote ought then to be taken. This stage would ensure that if any one of the nine staffs picked a petition as worthy of being granted, and were supported in this by its Justice, reconsideration of a negative result would ensue as a matter of course.

It might turn out that a preliminary check among the staffs, after each had completed its work on a group of petitions, but before the Justices' first votes were cast, would also be helpful; this would be very different from "pooling." 4 t

As a practical matter, I submit that following some such plan, to an approximation of a niceness such as would justify use of the label "chemically pure," would make it impossible that any petition would be denied, which would have been voted for by four Justices after the most prayerful consideration. I see no reason to think, either, that any more petitions would be "improvidently granted" than is now the case. This is probably all that can be said for any process of expedited consideration of one issue after another. And much reading time would plainly be saved.

There is a cost. The cost is that the Justice must place confidence, in many cases, in the accuracy and adequacy of the summaries prepared by his staff. I think the practical cost here would be very small; the system I have outlined would be so full of built-in checks, at two quite different levels, as to make an error in this regard a very rare occurrence. But there is some cost, in valuable ritual if not in practicality, and I would have to say, as the Study Group says of its own recommendation, that the question is not whether a plan is perfect, but whether it is less imperfect than its alternatives. ${ }^{48}$ The plan I have outlined would, to a very high degree of approximation, keep in the

47. The Study Group considered and rejected the alternative of placing control of the screening process in the hands of a senior staff responsible to the Court as a whole. See REPORT 15-I6; BICKeL, supra note 1, at 10.

48. See p. 894 supra. 
hands of the Court, Justice by Justice, the vital power to control its own flow of business. The Study Group's plan would in great measure take this power away. I have, therefore, no hesitation in urging that the plan I suggest can be implemented at far less cost than the Group's plan.

\section{B. An Inferior National Court}

Thus far I have chiefly treated the Group's recommendations as centering around the certiorari granting process. I think this is where its emphasis lies. But there is in the Report another suggestion: that the National Court of Appeals function as a court for resolving such intercircuit conflicts as are of insufficient importance to take up the Supreme Court's time.49 I think there is here more than just the germ of a good idea.

I would restate the function of a National Court of Appeals more loosely as that of deciding such questions as ought to be decided uniformly for the nation, where such questions are not, in the Supreme Court's judgment, so important as to make them suitable for the expenditure of its own time in full consideration. It seems to me that a new court might well be employed for this purpose and that there could be no constitutional or practical objection, provided the judgments of such a court were subject to being brought up by discretionary certiorari, before or after judgment, in the Supreme Court. There would be two routes to such a court: (1) a direct application to it or (2) a reference to it, by the Supreme Court, of cases deemed suitable for uniform national settlement, but tentatively considered not of sufficient importance to warrant full consideration in the Supreme Court itself. Such an arrangement would provide a means of procuring national uniformity on relatively unimportant issues in many fields-tax, admiralty, patents, and so on-while leaving the Supreme Court in flexible final control.

I would not define the business of such a court in terms of what the Study Group calls "true" intercircuit conflict.50 Many cases of such conflict can be endured and sometimes perhaps ought to be endured while judges and scholars observe the respective workings out in practice of the conflicting rules, particularly where the question of law is a close one, to which confident answer will in any case be impossible. On the other hand, firm assurance and settlement of national uniformity may be highly desirable, even though "true" intercircuit conflict has

49. See REPORT 18.

50. Id. 
not yet occurred in litigation. Visible tendencies or strong dicta may foreshadow conflict to come, even though it has not yet arisen in its "true" form, so that expectations, and the planning and counseling based on them, are clouded.

I also think that thought should be given to interstate conflicts on points of federal law and to the question of review of some state-court judgments in the new court on the basis of such conflicts. The attention of the profession has for some reason not been explicitly directed to this problem, but surely an important state-to-state conflict of this kind calls at least as pressingly for resolution as does "intercircuit" conflict.

It would be inevitable, and I think much to be desired, that if such a court (which could be manned by full-time, life-time federal judges on the constitutional plan) developed prestige and confidence, successful petitions for review of its judgments would be fairly rare, particularly where the decisions were unanimous or nearly so. This would save some of the Supreme Court's time-perhaps a great deal-and still leave the Supreme Court in final, total control.51

\section{Conclusion}

I would suggest, then, three things: (1) For certiorari applications, the controlled and carefully checked use of junior and senior staffs, responsible to each Justice individually, with cross-checking among the nine Justices after the tentative position of each has been formed; (2) the consideration, at least, of a single central court for bringing about national uniformity in relatively unimportant matters, with final control remaining, through discretionary review, in the Supreme Court; (3) as a regretfully taken third step, to be resorted to only after proven insufficiency of the other two, the elimination or selective curtailment of oral argument.

I insist that any of these steps, or any combination of them, is better than the Study Group's plan, which would sever decision from the choice whether to decide, a severance that goes to the life of supremacy.

51. The ABA House of Delegates has endorsed a plan for a 15-judge national division of the existing United States Court of Appeals. See Report of The Special Committee on Coordination of Judicial Improvements, 1973. I would not favor the ABA's suggestion that such a court might be confined to particular subjects or to review of the judgments of particular tribunals. See id. at 5 . The importance of a case cannot be defined in that way. There is much room for further study of the possibilities in a central, national court just below the Supreme Court. One experience that should be fully consulted is that of the British Court of Appeal in its relation with the House of Lords. See generally W. HoldsworTH, I A HIsTORY OF ENGLISH LAW 638-45 (rev. ed. 1956). 